"Consciousness implies choice, and thus the self is freedom: "the more consciousness, the more self; the more consciousness, the more will. . . A person who has no will at all is not a self.' For Kierkegaard, despair must be a free act, and not simply a characteristic of mankind." 


\section{SIN, DESPAIR, AND THE OTHER: The Works of Soren Kierkegaard}

SCOTT O'LEARY

SOREN KIERKEGAARD, THE MYSTIC EXISTENTIALIST, QUESTIONS THE ROLE OF DESPAIRING HUMAN LIFE IN HIS CELEBRATED TEXT, THE SICKNESS UNTO DEATH. IN ADISQUISITION BOTH PERSUASIVE AND TROUBLING, HE INSISTS THAT DESPAIR, FARFROM BEING A STATE OF CONSCIOUSNESS WHICH SHOULD BE AVOIDED, IS IN FACT ASPIRITUAL MOOD THAT BRINGS THE INDIVIDUAL DIALECTICALLY CLOSER TO THE DIVINE. BUT HOW CAN WE ACCEPT THE PARADOXES OF FAITH THAT CAUSE SUCH TERRIBLE DESPAIR? OUR INABILITY TO COME TO TERMS WITH THE ELEMENTS OF CHRISTIANITY THAT KIERKECAARD HIMSELF CALLS OFFENSIVE, SUCH AS ORIGINAL SIN AND GOD'S TOTAL AUTHORITY OVER MAN, LEAD TO A PERVASIVE LOSS OF SELF-CONSCIOUSNESS THAT KIERKEGAARD SEES AS THE EPIDEMIC OF MODERN CIVILIZATION. LIKE A PHYSICIAN, KIERKEGAARD DIAGNOSES OUR SICKNESS, AND HIS PRESCRIPTION FOR RECOVERY IS PARADOXICAL AND PROVOKING. 


\section{"For Kierkegaard, the self becomes impossible without the existence of a divine "other," who exists outside and beyond the human."}

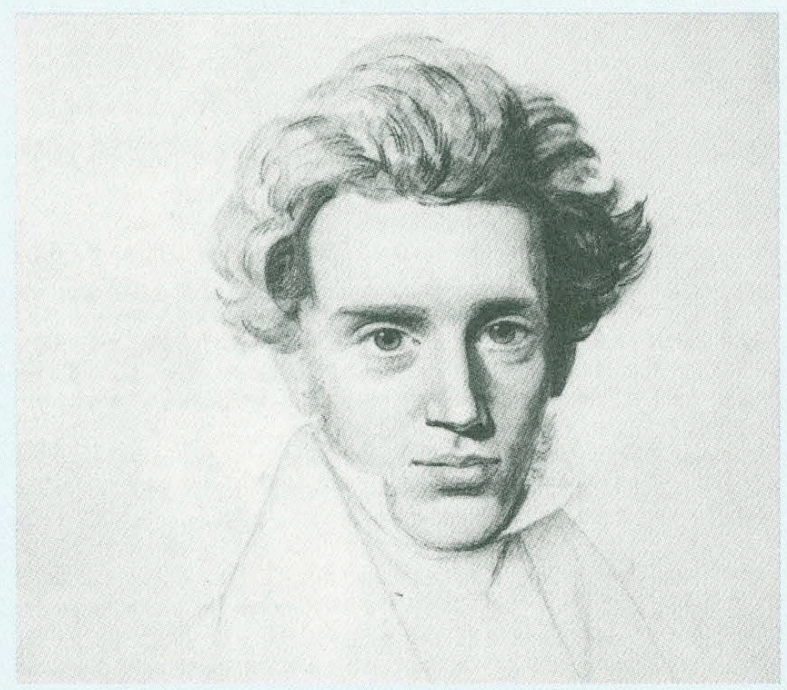

"Whereof one cannot speak, thereof one must be silent," writes Ludwig Wittgenstein at the end of his Tractatus Logico Philosophicus. Martin Heidegger is more explicit: "Theology is a positive science, and as such, therefore is absolutely different from philosophy"i. Many Continental and Analytic philosophers agree that the subject of God must remain apart from philosophy. However, Soren Kierkegaard protests precisely the opposite: Only a metaphysical system that removes the mystery of God must be avoided. Kierkegaard sees that man's problems lie in his sickness, a sickness caused by despair. It is only through a personal God that one can overcome despair.

In The Sickness unto Death, Kierkegaard develops a psychospiritual analysis of despair and illustrates that the only solution to this is a personal relationship with the divine 'other', God.ii The first section of this work shows how Kierkegaard develops despair as a psychological and spiri- tual mood that transcends finite existence. Following the theistic existential tradition of Augustine and Pascal, Kierkegaard elaborates on the understanding of despair as a being out of place in the world. Kierkegaard uses a psychological description of an underlying, primordial, and existential emotion as an important component of his solution to despair. For Kierkegaard, the self becomes impossible without the existence of a divine "other," who exists outside and beyond the human.

The Sickness unto Death is not without precedent. Soren Kierkegaard's work follows a tradition of Christian existential writing that began with Saint Augustine. In his Confessions, Augustine hints at the emotional analysis one finds at the heart of Kierkegaard's writing. The Confessions is a wholly existential work, and Augustine anticipates Kierkegaard by writing, "Thou madest us for Thyself, and our heart is restless, until it repose in Thee." iii

Blaise Pascal continues this tradition of theistic existentialism even amidst Enlightenment rationalism. Pascal writes of the human condition as a great fallen-ness, rendering the human being a miserable and weary entity. "Nothing is so insufferable to man as to be completely at rest, without passions, without business, without diversion, without study. He then feels his nothingness, his forlornness, his insufficiency, his dependence, his weakness, his emptiness." Through the intensity of emotional experience, man recognizes his weakness and despair, leading Pascal to remark, "We know the truth, not only by the reason, but also by the heart."iv

Kierkegaard is not alone in predicating religious and philosophical belief upon an emotional torment that he terms 
anxiety. Yet he sets himself apart, as this "restlessness and weariness"v become the focal point of his philosophical studies. The Sickness unto Death begins with the metaphor of the physician at a sickbed. Just as a physician examines the infirm to diagnose the problem and discover a cure, Kierkegaard depicts himself as a "physician of the soul" intent on resolving "a sickness of the spirit."vi The role of physician is established within the full title of the work: The Sickness unto Death: a Christian Psychological Exposition for Upbuilding and Awakening. The description of despair cannot be understood as a purely theoretical sketch, but instead, as a clinical and psychological analysis. The author clearly states that The Sickness unto Death is both a rigorous scholarly work and a religious exhortation to overcome the despair which leads to $\sin$. vii

Unlike other philosophers of his time, such as Hegel, Kierkegaard avoids any systematic definitions, preferring instead to use metaphorical examples. He also employs dialectics, in which a thesis and antithesis join to form a synthesis, to describe a number of his ideas, most notably that of the "self." In this sense, Kierkegaard incorporates Hegel's dialectical approach in his analysis, while at the same time refusing to reduce his ideas to a formal system. The Sickness unto Death begins with the conception of the self. In many ways, it is the divided self of Descartes, in which the individual subjective consciousness is the foundation for interpreting the world. Yet Kierkegaard adds certain qualifications. While he accepts the subjective self, Kierkegaard avoids the "false step" of Descartes' artificially created concept of "inwardness." viii

Yet, since Kierkegaard explains that since the health of the self is attained through faith, some form of inwardness is essential for the self. Like Descartes, he rejects the Aristotelian psychology of health as an outward self measured by social ethics, but in opposition to Descartes, Kierkegaard posits his own analysis: "A human being is spirit. But what is spirit? Spirit is the self." Unfortunately, this initial analysis of the self as spirit is not immediately useful. He adds, "But what is the self? The self is a relation that relates itself or is the relation's relating itself to itself in the relation." ix

Kierkegaard's complicated conception of the self can best be deciphered by a careful analysis of its parts. Firstly, we see that the self exists as a relation: it is not a substance or a single "point" of consciousness but instead can be conceived of as a "relational field." Through its simultaneous relation with itself, and a reaching beyond itself to related to the "other," the self becomes "concrete" in a synthesis of its finite and infinite qualities. xi For Kierkegaard, God is the ultimate "other," to whom the self is necessarily and absolutely related

\section{Such a relation that relates itself to itself must either have established itself or have been established by another. If the relation that relates itself to itself has been established by another, then the relation is indeed the third, but this relation, the third, is yet again a relation and relates itself to that which established the entire relation.}

\section{The Human self is such a derived, established relation, a relation that relates itself to itself and in relating itself to itself relates itself to another." xii}

The self arises from the divine other, and as such, the self can only be explored dialectically via the analysis of its relation to an "other."

The self's realization that it has not "itself established itself" leads to two forms of despair.xiii If the self did indeed establish itself, then there would be no dialectical conflict with the divine other. This position would closely reflect Heidegger and Sartre's interpretations, which portray despair in only a singular form. Yet Kierkegaard cannot agree with this. Whether this belief is solely on a religious level or also philosophical is an untenable question, as the two are inextricably linked in his thinking. The relational aspect of the self, the always-becoming and always-in-flux, requires this "other" to continually establish the self. 
Kierkegaard's perceives the human being is a series of three syntheses: "a synthesis of the infinite and the finite, of the temporal and the eternal, of freedom and necessity, in short, a synthesis,"and it is the mediating relation between these opposing pairs that constitutes the self.xiv Despair arises in the "mis-relation in a relation that relates itself to itself." $\mathrm{xv}$ In the possibility of each synthesis becoming a "mis-relation," there lurks the possibility of despair, which then must be traced dialectically.

That this is so is due to the dialectic inherent in the self as a synthesis, and therefore each constituent is its opposite. No kind of despair can be defined directly (undialectically) but only by reflecting on its opposite factor. $x$ vi

Rather than immediately engaging in this dialectic exploration, it is helpful to use Kierkegaard's ideas of the aesthetic, the ethical, and the religious as the three stages of life, and to compare these stages to the different types of despair present in the three forms of syntheses. The life of the aesthete, personified in Don Juan and Faustus, is a self that attempts to completely free itself from finitude, falling into the despair of infinitude. "This initial wakening to imagination...this passion for the possible," allows for infinite freedom and creativity; yet as Kierkegaard himself warns, "You are king of a kingdom of nothingness." xvii This infinite has no grounding in reality, and thus the aesthete is destined to a life of continuous self-creating. Like Prometheus, the aesthete's desire to become a god is impossible. "Such exercises in 'Promethean hope'," Kierkegaard admonishes, "invariably culminate in despair." xviii

The ethical life, by contrast, becomes grounded solely in the finite, the temporal, and the necessary. Characters such as Judge Wilhelm in Either/Or entirely lose their consciousness of the infinite and the eternal. While the ethical man chooses a self, he thinks only in relation outward, to others around him, neglecting the eternal quality of his soul.

Finally, with the famous example of Abraham, in Fear and Trembling as the "knight of faith," the author describes the third, and culminating, stage of life. The religious life is the synthesis of the aesthetic and ethical life, and in this sense reconciles the dialectical elements of the soul. The freedom, imagination, and possibility of the aesthetic are grounded in a necessity that is stronger than the ethical: the divine.

These three stages, the aesthetic, ethical, and religious stages, depict the self's outward relations. In The Sickness unto Death, Kierkegaard turns his attention to one's inner relations. Because this relation is inward, Kierkegaard relies on a dialectical, psychological, and more abstract mode of analysis. He avoids the concrete models of Abraham, Judge Wilhelm, and Faustus in favor of three distinct dialectical pairs : the temporal/eternal, the finite/infinite, and possibility/necessity. Each of these pairs is more than simply a collection of opposites, or a "negative unity". The synthesis of each of these dialectical pairs begets freedom, and this freedom is the grounded, concrete self. The self is the right relation between the six constituents of the synthesis, each of which, if it becomes unbalanced, can lead to its own form of despair. The temporal and eternal are discussed in great detail another work by Kierkegaard. xix In The Sickness Unto Death, he focuses upon the second two kinds of despair. In the first, the dialectical mis-relation of finite and infinite, the despair of finitude forgets the spiritual, the inifinite, and lives only for the day to day. By contrast, the despair in infinitude occurs when the self immerses itself in the spiritual and infinite, but loses its relation to the world, living entirely in fantasy and imagination. As for necessity and possibility, a balance of the two relations would function dialectically to prevent the self from becoming lost in endless and imaginative possibility, or trapped in the fatalism of necessity.

Though despair is intricately linked with this dialectic of self, it "must be considered primarily within the category of consciousness."xx Why is this so? Because for Kierkegaard, the "level" of the self's despair has a profoundly direct relation to the self's consciousness. Consciousness implies choice, and thus the self is freedom: "the more conscious- 
ness, the more self; the more consciousness, the more will...A person who has no will at all is not a self."xxi For Kierkegaard, despair must be a free act, and not simply a characteristic of mankind. All despair contains at least some element of consciousness, although "very often, the person in despair probably has a dim idea of his own state."xxii Even when one is ignorant of his despair as despair, he chooses to be in despair by not being conscious of himself as spirit.

The more developed forms of despair arise proportionally with an increase in self-consciousness. Consciously, one despairs by either willing to not be oneself, or willing to be oneself The first of these opposing states is a despair of weakness: the individual wills to be something or someone that is not his own self. A person cannot acknowledge the totality of his own selfhood, and thus resorts to a number of escapes: "in despair not to will to be oneself. Or even lower: in despair not to will to be a self. Or lowest of all: in despair to will to be someone else, to wish for a new self."xxiii What delineates the stages of this scale is the level of concealment of the self as self. The lowest form views the self simply as the outward living of an individual. When a man sheds his self and wants, for example, to be Caesar, Napoleon, or a bourgeois gentleman, he is hiding in weakness from his true self and from the conception of self as personal and internal. To despair either to not be a self or to not be oneself are also weaknesses because "in no way does it come from within as an act."xxiv This occurs because one despairs as a "man of immediacy," concerned only with the earthly and outward world. Or, having a real conception of the self, one falls into "inclosing reserve." The man of inclosing reserve acknowledges spirit in the self, but out of weakness goes no further; he resigns himself to an inexplicable solitude.

Proceeding one "dialectical step further," we reach the despair of defiance. The despair of defiance "is really despair through the aid of the eternal, the despairing misuse of the eternal within the self." xxv One in defiance wills to be oneself, but in a twisted and flawed manner, willing itself to relinquish its temporality through an act of stoicism and resignation, confirming only its abstractness. Or in another example the self attempts, through a Promethean imagination, to "reconstruct" itself in thought. As the author puts it, the "acting self...constantly relates itself to itself only by way of imagining constructs...It recognizes no power over itself." xxvi Both forms of defiance are despair, because they refuse to submit the self to the divine other, and instead defiantly challenge the other or simply falsely repudiate the temporality of the self.

Yet Kierkegaard makes clear that despair, while something that must be overcome, is a thing that points one towards a solution. As one's understanding of despair grows, the feeling of despair intensifies. "The level of consciousness intensifies the despair."xxvii This anticipates Kierkegaard's rejection that knowledge of despair can become the cure. The second half of The Sickness unto Death focuses on a possible solution, however, Kierkegaard does not claim to offer the solution. The divine other cannot be spoken of or fully understood, and thus even "transparently resting in the other" lacks complete certainty.xxviii

However, Kierkegaard sees the role of the other as central to a solution, as essential to the cure of this sickness unto death. The solution lies in the self, but as seen in Kierkegaard's description of the self, this cannot be found solely in the individual. He turns in the second half of The Sickness unto Death towards a possible solution, and at the same time turns from a primarily psychological description to a religious undertaking. While some like James L. Marsh see this as a division in the author's spheres of thoughts, our argument is that only in the religious can a solution be found.xxix Here, Kierkegaard links himself with the Christian tradition, bringing sin into the discussion. For here, the sickness "is sin and [sin] is: despair in not wanting to be oneself or wanting to be oneself." $x x x$ It is "sin" to be in despair "before God."xxxi $\mathrm{Sin}$ is despair at a more intense level, as the divine is higher than the human level. However, because all human beings are related to God as the other in the self, every human is in despair before God and therefore is also in sin. 
Kierkegaard rejects the Socratic belief that sin is ignorance. Knowing what is right does not necessitate acting rightly. "The Greek mind does not have the courage to declare that a person knowingly does wrong."xxxii Instead, Kierkegaard contends that the will chooses to sin. "Therefore, interpreted Christianly, sin has its roots in willing, not in knowing, and this corruption of willing affects the individual's consciousness."xxxiii Rather than knowledge producing a solution, despair increases with the understanding of despair. This leads the individual to seek a cure, forcing him to choose between despairing in sin and resting transparently in God. Sin must be a choice and not simply the 'human condition'. In the will, in willing to be oneself, an individual begins to overcome despair. However, willing alone is incomplete. A person cannot simply will a solution to $\sin$; he has need of the divine other.

Despair as sin is singularly before God. Like King David, Kierkegaard can say, "Against you, you alone, I have sinned."xxxiv The relationship between sin and despair is inside the self, as the "other" is part of the self. It follows logically, then, that a solution must also be inward. As sin is singular and personal before God, so is the solution to sin: faith. Man overcomes despair by resting transparently in God, and thus, "[b]y relating itself to its own self and by willing to be itself, the self is grounded transparently in the Power which constituted it." xxxv Without the divine other, the self cannot completely will to be itself. The self lacks the constitutive power that created it, and yet remains still part of the self.

An individual, which is a self always in flux, cannot cure himself of the sickness caused by despair. Only through God, through faith, can the self find a peace that comes from acceptance of the other. One cannot strive beyond what Kierkegaard describes as the aesthetic sphere without an 'other'. Kierkegaard sees the only possible solution in the self's relation to the divine other, yet even this remains uncertain only with fear and trembling.

\section{ENDNOTES}

i Heidegger (1988)

ii For brevity and simplicity I use Kierkegaard in place of 'AntiClimacus' and his other pseudonyms throughout this work, understanding that while Kierkegaard used a variety of perspectives, I am mainly concerned with the writing and thinking of Anti-Climacus. Examples from other writings are used to reinforce and clarify certain points.

iii Augustine (I993)

iv Pascal (I94I)

v Pensées, Fragment I3I.

vi Kierkegaard (I980)

vii The Sickness Unto Death, 5.

viii Westphal (1987)

ix The Sickness unto Death, p. I3.

x Mooney (1996)

xi The Sickness unto Death, p. 30.

xii The Sickness unto Death, p. I3-I4.

xiii The Sickness unto Death, p. I6.

xiv The Sickness unto Death, p. 13.

xv The Sickness unto Death, p. I42.

xvi The Sickness unto Death, p. 30.

xvii The Sickness unto Death p. 207.

xviii The Sickness unto Death, p. 207.

xix See Lowrie (1944)

$\mathrm{xx}$ The Sickness unto Death, p. 29.

xxi The Sickness unto Death, p. 29.

xxii The Sickness unto Death, p. 48 .

xxiii The Sickness unto Death, p. 52.

xxiv The Sickness unto Death, p. 51.

xxvThe Sickness unto Death, p. 67.

xxvi The Sickness unto Death, p. 68 .

xxvii The Sickness unto Death, p. 48 .

xxviii The Sickness unto Death, p. 30, I24.

xxix James Marsh in "Kierkegaard's Double Dialectic of Despair and Sin" divides The Sickness unto Death into the religious and

ethical spheres, stressing the dialectic between each. However,

he himself writes that there is only a single dialectic but two different 'aspects'.

xxx The Sickness unto Death, p. 77.

xxxi The Sickness unto Death, pII3

\section{REFERENCES}

\section{PRIMARY WORKS}

Augustine, Saint, Bishop of Hippo. Confessions trans. F.J.

Sheed. Indianapolis IN: Hackett Publishing Company, I993

Heidegger, Martin. Being and Time. trans. JohnMacquarrie and Edward Robinson. NewYork: Harper and Row Publishers, 1962

Heidegger, Martin. "Phenomenology and Theology" in Pathmarks, ed. William McNeill New York: Cambridge Univ. Press, I9 88 
Kierkegaard, Soren. The Concept of Dread. trans. Walter Lowrie. New Jersey: Princeton University Press, 1944

The Sickness unto Death. trans. Howard V. Hong and

Edna H. Hong. New Jersey: Princeton University Press, I980

Pascal, Blaise. Pensées. trans. W.F. Trotter. New York:

The Modern Library, I94I

\section{SECONDARY WORKS}

Caputo, John D. Radical Hermeneutics: Repetition,

Deconstruction, and the Hermeneutic Project. Bloomington:

Indiana University Press, 1987

Dreyfus, Hubert and Jane Rubin. "You Can't Get Something for Nothing: Kierkegaard and Heidegger and How Not to

Overcome Nihilism" Inquiry. March 1987; 30:33-75

Dreyfus, Hubert L. Being-in-the-World: a Commentary on Heidegger's Being and Time. Cambridge, Mass: MIT Press, I99I.

Gouwens, David. Kierkegaard as Religious Thinker. New York: Cambridge University Press, 1996

Kearney, Richard. Modern Movements in European Philosophy. Wolfeboro, New Hampshire: Manchester University Press, I987

The Wake of Imagination: Toward a Postmodern Culture. Minneapolis: University of Minnesota Press, I988

Marsh, James L. "Kierkegaard's Double Dialectic of Despair and Sin" International Kierkegaard Commentary: The Sickness unto Death ed. by Robert Perkins. Macon, Georgia: Mercer University Press, 1987

Mooney, Edward F. Selves in Discord and Resolve. New York: Routledge Publishing, 1996

Ree, Jonathan and Jane Chamberlain ed. Kierkegaard: A Critical Reader Oxford, UK: Blackwell Publishing, 1998

Westphal, Merold. “Kierkegaard's Psychology and Unconscious Despair" International Kierkegaard Commentary: The Sickness unto Death ed. by Robert Perkins. Macon, Georgia: Mercer University Press, 1987

Wyschogrod, Michael. Kierkegaard and Heidegger: The Ontology of Existence. New York: Humanities Press, 1969 